\title{
Grazing Intensity, Aspect, and Slope Effects on Limestone Grassland Structure
}

\author{
Ibone Amezaga, ${ }^{1}$ Sorkunde Mendarte, ${ }^{1}$ Isabel Albizu, ${ }^{1}$ \\ Gerardo Besga, ${ }^{1}$ Carlos Garbisu, ${ }^{1}$ and Miren Onaindia ${ }^{2}$
}

\author{
Authors are ${ }^{1}$ range management scientists, Department of Agrosystems and Animal Production, NEIKER, A. B. \\ (Basque Institute of Agricultural Research and Development), Berreaga 1, E-48160 Derio, Spain; and \\ ${ }^{2}$ Reader in Ecology, Department of Plant Biology and Ecology, Faculty of Sciences, University of the Basque Country, \\ P.O. Box 644, E-48080 Bilbao, Spain. At the time of the research, Amezaga was a Lecturer in Ecology at the \\ same Department of Plant Biology and Ecology.
}

\begin{abstract}
Three treatments were used to evaluate the effect of grazing intensity (ca $30 \%$ and $50 \%$ herbage removal), aspect (north and south), and slope ( $<10 \%$ and $10 \%-30 \%$ ) on plant community structure of mountain grasslands in the Basque Country (Spain). Plant species richness was not significantly affected by grazing intensity, aspect, or slope. Although plant species composition was similar (Sorensen's similarity index $=0.87$ ) between both grazing intensities, species frequency and cover were affected by grazing intensity. Festuca rubra L. and Agrostis capillaris L. were the most common species under both grazing pressures. Moderate grazing intensity $(50 \%$ herbage removal) plots contained a greater number of plant species with a frequency of more than $50 \%$. The lowest cover for F. rubra corresponded to low grazing intensity, north aspects, and steeper slopes. The lowest cover for A. capillaris was found under low grazing intensity ( $30 \%$ herbage removal) and steeper slopes. Danthonia decumbens (L.) P. C., Potentilla erecta (L.) Räuschal, and Trifolium repens L. were significantly affected by aspect and grazing intensity. Low grazing intensity on sites with northern aspects and steep slopes favored Agrostis curtisii Kerguélen, a species with a low nutritional value. A. capillaris, A. curtisii, P. erecta, and T. repens were sensitive to soil properties and aspect. Nitrogen and $\mathrm{K}$ soil concentrations were significantly higher in areas with low grazing intensity, most likely due to greater dead herbage accumulation. Significant $(P<0.05)$ correlations between plant species and soil $\mathrm{pH}$ or $\mathrm{P}$ concentration were found in areas with low grazing intensity. Reduction in grazing intensity together with the effect of slope and northern aspect has resulted in changes in plant community structure, leading to increases in forages with lower nutritional value.
\end{abstract}

\section{Resumen}

El objetivo de este estudio fue la evaluación del efecto de la intensidad de pastoreo (aproximadamente $30 \%$ y $50 \%$ de utilización de pasto), la orientación (norte y sur), y la pendiente $(<10 \%$ y $10 \%-30 \%)$ sobre la estructura de la comunidad vegetal en pastos de montaña del País Vasco (España). Ninguno de estos parámetros afectó de forma significativa a la riqueza de especies. Aunque la composición florística era similar (índice de Sorensen $=0.87$ ) en parcelas sometidas a las dos intensidades de pastoreo, la frecuencia de especies y su cobertura sí fueron afectadas por la intensidad de pastoreo. Las dos especies más frecuentes en parcelas sometidas a cualquiera de las dos intensidades de pastoreo fueron Festuca rubra L. y Agrostis capillaris L. Las parcelas con una intensidad moderada ( $50 \%$ de utilización de pasto) presentaban un número mayor de especies con una frecuencia superior a $50 \%$. La cobertura más baja para F. rubra correspondió a parcelas con baja intensidad ( $30 \%$ de utilización de pasto) de pastoreo, orientación norte, y pendiente más pronunciada. La cobertura más baja para A. capillaris se encontró en parcelas con baja intensidad de pastoreo y pendiente más pronunciada. Tanto la orientación como la intensidad de pastoreo afectaron de forma significativa a especies como Danthonia decumbens (L.) P. C., Potentilla erecta (L.) Räuschal, y Trifolium repens L. La baja intensidad de pastoreo en parcelas con orientación norte y pendiente más pronunciada favoreció el crecimiento de $A$. curtisii Kerguélen, una especie que presenta un valor pascícola bajo. Las concentraciones de $\mathrm{N}$, y $\mathrm{K}$ en suelo fueron significativamente superiores en las parcelas de intensidad de pastoreo moderada, probablemente debido a una mayor acumulación de necromasa vegetal. Se encontraron correlaciones significativas entre especies de plantas y $\mathrm{pH}$ del suelo y concentración de $\mathrm{P}$ en las parcelas sometidas a baja intensidad de pastoreo. La reducción en la intensidad de pastoreo junto con el efecto de la pendiente y la orientación norte ha causado cambios en la estructura de la comunidad vegetal, reduciendo el valor pascícola de los pastos.

Key Words: forage nutritional value, mountain pastures, plant community structure

\section{Introduction}

Research was funded by the Department of Agriculture and Fisheries, Basque Government. I.A. was the recipient of the "Basque Fellowship of Eusko Ikaskuntza" at Saint Antony's College, University of Oxford, UK.

Correspondence: Dr Ibone Amezaga, Department of Agrosystems and Animal Production, Basque Institute of Agricultural Research and Development, Derio, Spain. Email: gvzamari@ig.ehu.es

Manuscript received 18 November 2003; manuscript accepted 21 July 2004.
Mountain grassland systems are affected by a combination of physical and environmental factors, as well as by grazing and human activity. Calcareous seminatural grasslands are among the most species-rich communities in temperate Europe (van der Maarel and Titlyanova 1989; Kull and Zobel 1991). Nowadays, these ecosystems are threatened by changes in land use.

Land abandonment (with its concomitant livestock grazing reduction) and eutrophication are major threats to traditional 
pastoral landscapes (Bockdam and Gleichman 2000; Canals and Sebastia 2000), leading to progressive changes in these ecosystems (Bignal 1998; Ostermann 1998; Webb 1998). Reduction or exclusion of grazing from areas that have a long history of grazing can be considered a disturbance (Milchunas et al 1988; West 1993). Nevertheless, little is known about the long-term effects of changing land use on landscape structure and conservation values of European mountain pastures (McCracken and Bignal 1998; Watkinson and Ormerod 2001).

Herbivores are major determinants of structure and organization of plant communities (Milchunas and Lauenroth 1993; Berg et al 1997; Chase et al 2000; Gillen et al 2000; Bai et al 2001). Herbivores affect plant community structure by selective foraging, trampling, inducing physiological changes, and changing competition parameters among species (Kobayashi et al 1997; Stohlgren et al 1999; Gillen et al 2000; Bai et al 2001; McIntyre and Lavorel 2001), leading to important effects on net primary production, nutrient cycling, and redistribution of nutrients in plant species and landscapes (McNaughton 1985; Biondini et al 1998). Topographic conditions, such as aspect and slope, also affect pasture diversity and can have an important influence on its structure (Watkinson and Ormerod 2001).

In the Basque Country (northern Spain), mountain pastures cover $20 \%$ of the territory and most of them are on limestone. A reduction in economic revenue is leading to a reduction in agricultural practices, especially in mountain pastures where grazing has occurred since the Neolithic (Barandiaran and Manterola 2000). As abandonment of agricultural land leads to a progressive reduction in livestock grazing, more effective grazing regimes are needed to preserve these ecosystems. Grazing is one of the central and pivotal issues affecting grasslands, linking their maintenance, productivity, economic use, and management for biodiversity (Watkinson and Ormerod 2001). Maintenance of these pastures requires knowledge of the effects of grazing intensity on the structure, plant diversity, and underlying ecological processes of vegetal succession and nutrient cycling (McCracken and Bignal 1998).

The present study was conducted to determine the effect of grazing intensity and topographic conditions, namely aspect and slope, on plant community structure and soil characteristics of limestone mountain pastures.

\section{Materials and Methods}

\section{Study Area}

This study was conducted in the Gorbeia Natural Park (Basque Country, northern Spain), lat $43^{\circ} 07^{\prime} \mathrm{N}$, long $2^{\circ} 51^{\prime} \mathrm{W}$. The park is located in a mountain range where Gorbeia itself is the name given to the highest mountain ( $1482 \mathrm{~m}$ ) found there. Mean temperature and precipitation in the area are $10.1^{\circ} \mathrm{C}$ and $2000 \mathrm{~mm}$, respectively. Gorbeia Natural Park includes 1452 ha of grassland $(7 \%$ of the park surface), mainly on limestone soils. These grasslands replaced the original beech forests and have been maintained since Neolithic times by the grazing activity of wild (deer) and domestic (sheep, cattle, horses, and goats) animals (Aseguinolaza et al 1996; Barandiaran and Manterola 2000). The most common plant species in these seminatural grasslands is Festuca rubra L., in association with Agrostis capillaris L., Trifolium repens L., Gallium saxatille L., and Potentilla erecta
(L.) Räuschal. (Aseguinolaza et al 1996). This grassland community is of considerable agricultural importance because of its productivity and nutritional value for livestock (Albizu et al 1999). Traditional silvopastoral management in this area maintains cattle and horses in mountain grasslands throughout the year, while sheep are kept there only from May to October.

Limestone grasslands from areas with similar temperatures, topography, and altitude (900 to $1100 \mathrm{~m}$ ) were chosen for this study. Within these mountain grasslands, livestock herds graze freely, following similar daily patterns, thus creating different grazing intensities in the grasslands. Parts of these pastures have been experiencing a livestock reduction for the last 30 years (Albizu et al 1999). These mountain grasslands have a historical stocking rate of 1.0 animal unit month (AUM) ha ${ }^{-1}$. However, land abandonment has reduced this stocking rate in some areas to values as low as $0.7 \mathrm{AUM} \mathrm{ha}^{-1}$.

\section{Methods}

The study was carried out in 2 management units of 120 ha each where animals moved freely. The experimental design was a completely randomized block design with 4 replicates. Plots $(100 \times 100 \mathrm{~m})$ within randomly selected areas were defined and grazing intensity, aspect, and slope recorded. Grazing intensity was estimated by visual inspection (animal monitoring) (Manly et al 1993) as well as from the information provided by farmers and previous studies (Marijuan 1996; Albizu et al 1999). Two grazing pressures were defined: 1) a moderate grazing intensity $(50 \%$ herbage removal) and 2$)$ a low grazing intensity $(30 \%$ herbage removal). In this area the average annual herbage production is approximately $6500 \mathrm{~kg} \mathrm{ha}^{-1} \mathrm{y}^{-1}$ (Albizu et al 1999). Apart from grazing intensity, 2 more variables were studied, ie, aspect (north and south) and slope $(<10 \%$ and $10 \%-30 \%)$. Vegetation and soil sampling were conducted in spring, at the peak of primary production. Within each plot, 30 randomly chosen quadrats $(0.5 \mathrm{~m} \times 0.5 \mathrm{~m})$ were sampled. The abundance of each species was assessed by visual estimate of foliar cover in terms of occupied surface to the nearest $5 \%$. Species cover was expressed as percentage of total cover.

Twelve soil samples $(10 \mathrm{~cm}$ depth, $3 \mathrm{~cm}$ diameter $)$ were randomly collected within each plot. Soil samples from each site were pooled and analyzed for $\mathrm{pH}$ in water (soil solution ratio of 1:2.5), and $\mathrm{N}, \mathrm{P}$, and $\mathrm{K}$ concentration. Nitrogen was determined by the Kjeldahl method, $\mathrm{P}$ by colorimetry (Kontron Instruments, UVIKON 930, United Kingdom), and K by flame atomic absorption spectrophotometry (Varian, SpectrAA-250 plus, Walnut Creek, CA) according to MAPA (1994).

\section{Data Analysis}

The Shannon-Wiener index was used to calculate plant diversity on the basis of foliar cover (Shannon and Wiener 1963). Sorensen's similarity index was calculated for grazing intensity using data pooled over aspect and slope (Kent and Coker 1992). Species richness, cover, and soil characteristics were analyzed by analysis of variance. Only species with cover values higher than $5 \%$ were included in the cover comparisons. Frequency distributions for plant species between grazing intensities were expressed for the entire plant community (because, in our study, it was intended to reflect the change for the community as a whole) and analyzed by Chi-square tests 
Table 1. Plant species recorded in the study, including their mean ( $\pm \mathrm{SE}$ ) cover values (\%) for moderate $(50 \%$ herbage removal) and low ( $30 \%$ herbage removal) grazing intensity plots.

\begin{tabular}{ll}
\hline & \multicolumn{2}{c}{ Grazing intensity } \\
\cline { 2 - 3 } Species & Moderate Low
\end{tabular}

\section{Grasses}

Agrostis capillaris L.

Agrostis curtisii Kerguélen

Avenula pratensis (L.) Dumort

Briza media L.

Danthonia decumbens (L.) D.C.

Festuca rubra $\mathrm{L}$.

Molinia caerulea (L.) Moench

Poa annua $\mathrm{L}$.

Pseudoarrenatherum Iongifolium

(Thore) Rouy

Forbs

\section{Aira praecox $\mathrm{L}$.}

Anthemis nobilis $\mathrm{L}$.

Bellis perennis $\mathrm{L}$.

Carex caryophyllea Latourr.

Carex sp.

Cerastium fontanum Baumg.

Cirsium eriophorum (I.) Scop

Eryngium bourgatii Gouan

Erytrhronium dens-canis $\mathrm{L}$.

Galium saxatile $\mathrm{L}$.

Gentiana lutea L. subsp lutea

Hieracium pilosella $\mathrm{L}$.

Jasione laevis Lam. Subsp laevis

Juncus squarrosus $L$.

Leontodon hispidus $\mathrm{L}$.

Luzula campestris (L.) D.C.

Nardus stricta L.

Plantago media L.

Polygala serpyllifolia J.A.C. Hose

Potentilla erecta (L.) Räuschel

Potentilla montana Brot.

Prunella vulgaris $\mathrm{L}$.

Ranunculus bulbosus $\mathrm{L}$.

Ranunculus parviflorus $\mathrm{L}$.

Scilla verna Hudson

Sedum sp.

Senecio helenitis (L.) Schinz et Thell.

Serratula seoanei (Willk.)

Stellaria holostea L.

Taraxacum gr officinale G.H. Weber ex Wiggers

Veronica arvensis $\mathrm{L}$.

Veronica officinalis $L$.

Legumes

Lathyrus limifolius (Reich) Bässler

Lotus corniculatus L.

Trifolium repens $\mathrm{L}$. subsp repens

$\begin{array}{cc}17.9 \pm 2.3 & 17.5 \pm 3.4 \\ 5.0 \pm 2.8 & 7.3 \pm 3.3 \\ 2.1 \pm 1.0 & 0.3 \pm 0.2 \\ -1 & t \\ 5.0 \pm 1.4 & 5.7 \pm 1.4 \\ 28.2 \pm 3.0 & 19.8 \pm 3.1 \\ - & 0.9 \pm 0.5 \\ 0.5 \pm 0.3 & 1.0 \pm 0.2\end{array}$

t

-

$1.9 \pm 1.2$

$1.5 \pm 0.8$

$3.0 \pm 1.1$

$t$

$1.2 \pm 0.5$
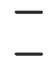

$\mathrm{t}$

$2.3 \pm 0.8$

$0.6 \pm 0.3$

$3.4 \pm 1.3$

-

$t$

$0.2 \pm 0.1$

$3.2 \pm 0.7$

$t$

$0.9 \pm 0.5$

$\begin{array}{ll}0.2 \pm 0.2 & 0.3 \pm 0.2 \\ 4.0 \pm 0.9 & 5.0 \pm 1.4\end{array}$

$\mathrm{t}$

$0.1 \pm 0.1$

-

$\mathrm{t}$

$0.1 \pm 0.1$

$t$

$0.3 \pm 0.2$

$0.6 \pm 0.4$

$\mathrm{t}$

$0.2 \pm 0.2$

$0.6 \pm 0.3$

- $\quad 0.1 \pm 0.1$

$1.9 \pm 0.7$

$1.8 \pm 0.7$

Veronica officinalis

Leontodon hispidus

Hieracium pilosella

Potentilla erecta
Grazing intensity

Moderate Low

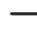

$0.3 \pm 0.3$

$0.8 \pm 0.6$

$0.4 \pm 0.4$

$0.4 \pm 0.4$

$0.2 \pm 0.2$

$\mathrm{t}$, mean cover lower than $0.1 \%$. 

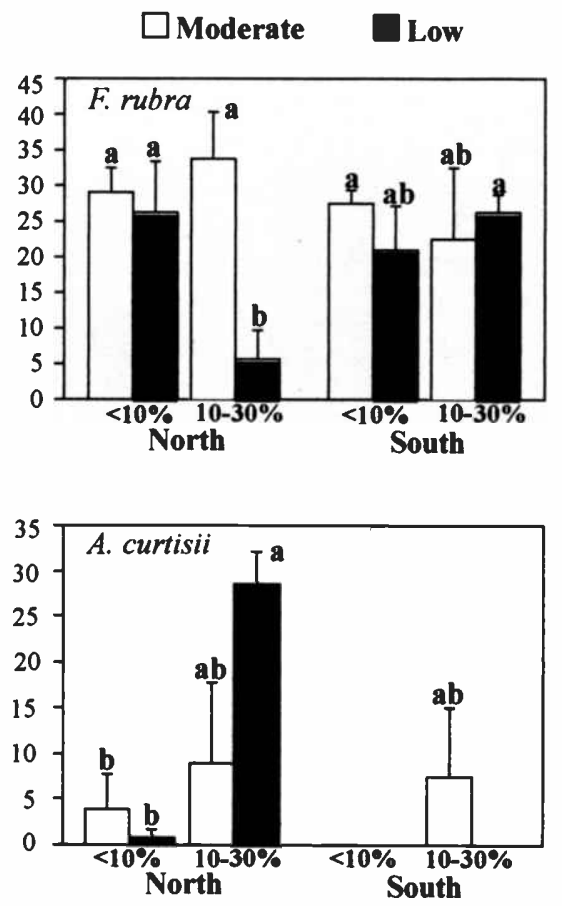

Figure 1. Grazing intensity ( $30 \%$ and $50 \%$ herbage removal), aspect (north and south), and slope ( $<10 \%$ and $10 \%-30 \%$ ) effect on Festuca rubra and Agrostis curtisii cover (\%). Means with the same letter are not significantly different $(P<0.05)$.

sampling quadrats, respectively (Table 2 ). The most frequent species under both grazing intensities were $F$ rubra and $A$. capillaris. The third most frequent species observed in the moderate and low grazing intensity plots was Hieracium pilosella $(82 \%)$ and $T$. repens $(68 \%)$, respectively.

F. rubra was affected by the interaction among grazing intensity, slope, and aspect $(P<0.05)$. The lowest $F$. rubra cover corresponded to low grazing intensity, north-facing, steeper slopes (10\%-30\%) (Fig. 1). Mean cover of $A$. curtisii, a species with low nutritional value for cattle, was affected by the interaction among grazing intensity, aspect, and slope $(P<0.05)$. The highest cover values were found on lowgrazing-intensity, north-facing, steeper slopes (Fig. 1). Mean

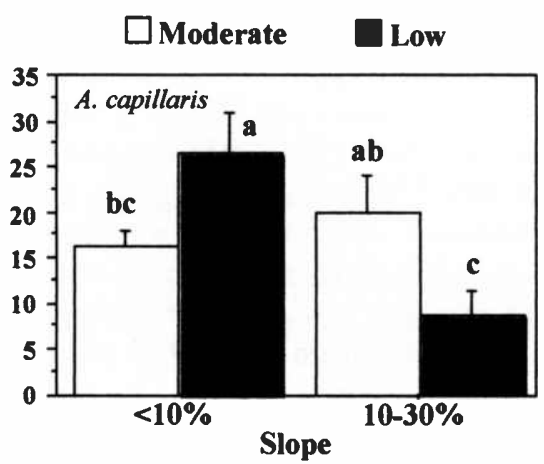

Figure 2. Grazing intensity ( $30 \%$ and $50 \%$ herbage removal) and slope $(<10 \%$ and $10 \%-30 \%)$ effect on Agrostis capillaris cover $(\%)$. Means with the same letter are not significantly different $(P<0.05)$.
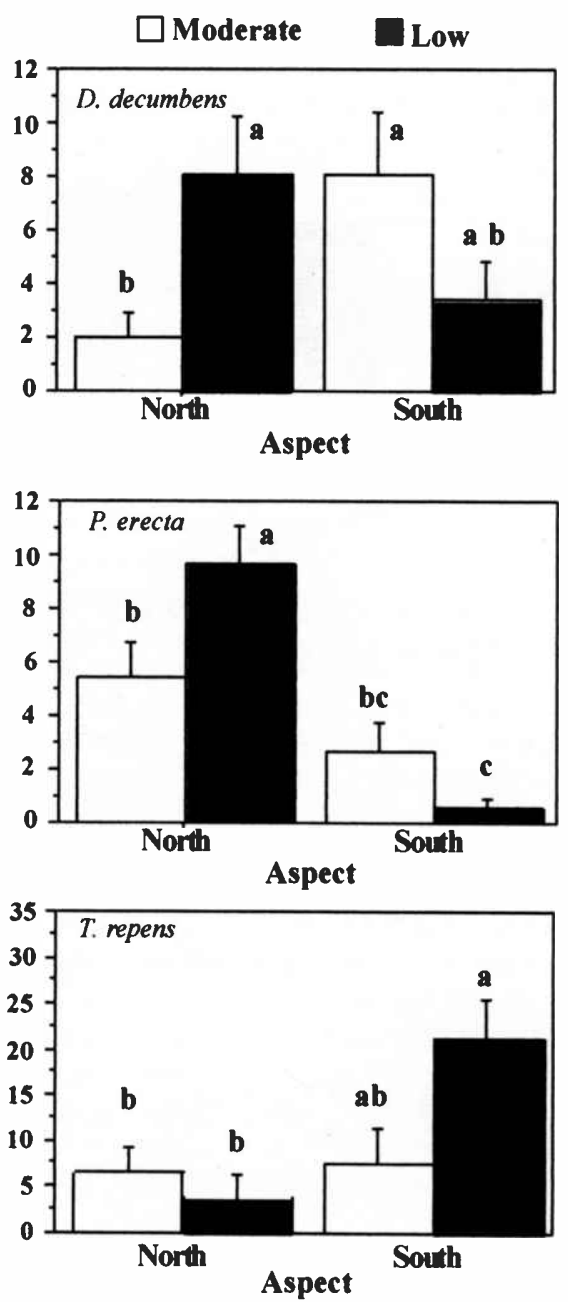

Figure 3. Grazing intensity (30\% and $50 \%$ herbage removal) and aspect (north and south) effect on Danthonia decumbens, Potentilla erecta, and Trifolium repens cover (\%). Means with the same letter are not significantly different $(P<0.05)$.

cover of $A$. capillaris was affected by the interaction between grazing intensity and slope $(P<0.01)$, with lowest values found under low grazing intensity and steeper slopes (Fig. 2). Danthonia decumbens, $P$. erecta, and $T$. repens were affected by the interaction between grazing intensity and aspect. $D$. decumbens showed the lowest cover values in north-moderate grazing intensity plots (Fig. 3). P. erecta had the lowest cover values in south-low grazing intensity plots, whereas $T$. repens had its highest values on these same sites (Fig. 3).

Plant diversity was unaffected $(P<0.05)$ by grazing intensity, slope, or aspect. Under moderate and low grazing intensity, mean plant diversity was $1.87 \pm 0.01$ and $1.93 \pm 0.02$, respectively.

\section{Soils}

The interaction between grazing intensity and aspect had an effect on soil $\mathrm{pH}(P<0.05)$, but no slope effect was observed for this same parameter. The highest $\mathrm{pH}$ values were recorded on low-grazing-intensity, south-facing plots (Fig. 4).

$\mathrm{N}$-Kjeldhal was affected only by grazing intensity $(P=0.01)$. The highest $\mathrm{N}-\mathrm{Kjeldahl}$ values were found at the 


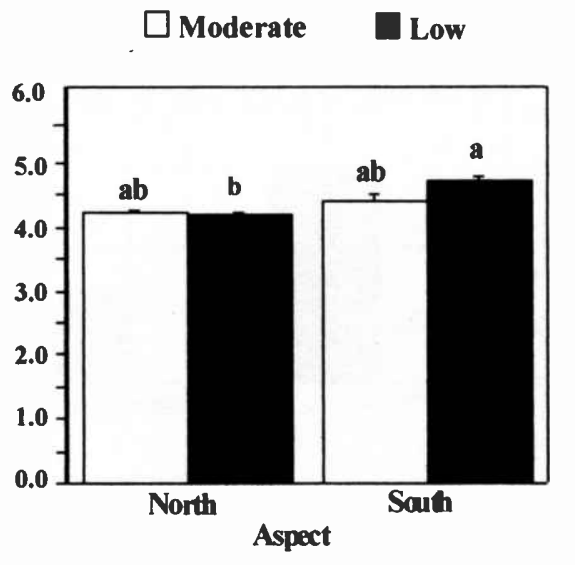

Figure 4. Grazing intensity ( $30 \%$ and $50 \%$ herbage removal) and aspect (north and south) effect on soil pH.

low grazing intensity. Phosphorus concentration was signifcantly affected by grazing pressure and slope $(P<0.01)$, with the lowest values found on low-grazing-intensity plots with slopes of more than $10 \%$ (Fig. 5).

Potassium concentration was significantly affected by grazing intensity $(P<0.05)$, but unaffected by slope or aspect. Plots with low grazing intensity had higher $K$ concentration values (mean $=231$ parts per million [ppm], $\mathrm{SE}=31.1$ ) as compared to the more heavily grazed plots (mean $=144 \mathrm{ppm}, \mathrm{SE}=8.3$ ).

\section{Soil and Vegetation}

More significant correlations between plant species and soil characteristics were observed at low than at moderate grazing intensity (Table 3 ). Under moderate grazing intensity, only the correlation between Serratula seoanei and soil $\mathrm{pH}$ was significant $(P<0.05)$. Alternatively, under low grazing intensity, 11 species were correlated either with soil $\mathrm{pH}$ or $\mathrm{P}$ concentration.

\section{Discussion}

Grazing intensity was the factor most consistently affecting plant community structure, either by itself or interacting with aspect and slope. Nevertheless, grazing intensity did not affect species richness, in agreement with other works (McNaughton 1985; Huntly 1991; Stohlgren et al 1999; Bai et al 2001). Sorensen's similarity index $(0.87)$ showed a small difference between the species present at moderate and low grazing intensities. Plant species found under only one grazing intensity were present in low frequencies and cover.

Grazing intensity affected plant community structure in three different ways. First, although $F$. rubra and A. capillaris were the dominant species under both grazing intensities, their frequencies were lower under low grazing intensity. The ranking of the most frequent species was also different, indicating, according to some authors (Tansley and Adamson 1925; Hik et al 1992), differences in plant community structure.

Second, grazing intensity had a significant effect on species cover. F. rubra and A. capillaris (2 species of high nutritional values for livestock) (Daget and Poissonet 1972; Albizu et al 1999) were affected by the interaction between grazing pressure

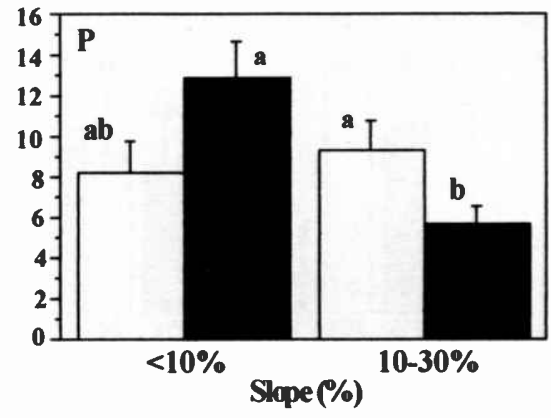

Figure 5. Grazing intensity ( $30 \%$ and $50 \%$ herbage removal) and slope $(<10 \%$ and $10 \%-30 \%)$ effect on $P$ soil concentration. Means with the same letter are not significantly different $(P<0.05)$.

and slope, as previously reported by Marriott et al (2002). The cover of these 2 species decreased with reduced grazing pressure, as observed for Bouteloua gracilis [(Kunth) Lag. Ex Griffiths] and Buchloë dactyloides [(Nutt.) Engelm.] (Hart and Ashby 1998).

Third, reduction in grazing intensity changed soil conditions that, in turn, affected plant species distribution, for instance, that of $T$. repens and $A$. capillaris. Low grazing intensity has been reported to favor nutrient accumulation, thus affecting the establishment of plant species (Mikola et al 2001). A. curtisii, a good competitor under these conditions but with low palatability to livestock (Daget and Poissonet 1972; Albizu et al 1999), was negatively correlated with $P$ concentration. This species is favored by low P soil concentrations, usually found in steep slopes, as has been observed for Deschampsia caespitosa under reduced grazing pressure (Foster and Gross 1998; Xiong and Nilsson 1999; Krahulec et al 2001; Reeder and Schuman

Table 3. Correlation matrix (Spearman's rank correlation) for the most frequent plant species and edaphic parameters, ie, $\mathrm{pH}$ and $\mathrm{P}$ concentration (parts per million [ppm]), in the low ( $30 \%$ herbage removal) and moderate ( $50 \%$ herbage removal) grazing intensity plots.

\begin{tabular}{lcc}
\hline Species & $\mathrm{pH}$ & $\mathrm{P}(\mathrm{ppm})$ \\
\hline Low grazing intensity & & \\
Agrostis capillaris & 0.003 & $0.65^{*}$ \\
Agrostis curtisii & -0.22 & $-0.62^{*}$ \\
Bellis perennis & $0.83^{* *}$ & 0.13 \\
Carex sp. & $-0.57^{*}$ & 0.26 \\
Cerastium fontanum & 0.48 & $0.55^{*}$ \\
Hieracium pilosella & 0.02 & $-0.52^{*}$ \\
Molinia caerulea & 0.28 & $-0.54^{*}$ \\
Potentilla erecta & $-0.76^{* *}$ & -0.38 \\
Potentilla montana & $0.67^{* *}$ & 0.04 \\
Serratula seoanei & $-0.55^{*}$ & 0.10 \\
Trifolium repens & $0.63^{*}$ & 0.27 \\
Moderate grazing intensity & & \\
Serratula seoanei & $-0.54^{*}$ & 0.04 \\
\hline
\end{tabular}

Level of significance: $*, P<0.05 ; * *, P<0.01$. 
2002). D. caespitosa is also an unpalatable species, of low nutritional value, in European mountain pastures (Daget and Poissonet 1972; Albizu et al 1999).

Decreases in soil nutrient concentration as a result of grazing reduction have been reported by different authors (Dormaar and Willms 1990; Frank et al 1995; Manley et al 1995), whereas others have not found any relation between grazing intensity and soil nutrient concentration (Milchunas and Lauenroth 1993; Mathews et al 1994; Biondini et al 1998; Bullock et al 2001). In general, our results showed higher soil $\mathrm{pH}$, and $\mathrm{N}, \mathrm{P}$, and $\mathrm{K}$ concentrations at low grazing intensity. This might be due to higher accumulation of dead herbage at the low grazing intensity (Lavado et al 1996; Albizu et al 1999), leading to greater amounts of these minerals in the soil (Dormaar and Willms 1990; Biondini et al 1998). In addition, it is likely that the export of nutrients by herbivores might have been lower under the low grazing intensity. Reduced grazing intensity probably results in part of the net primary production being converted to dead herbage, retarding the cycling of these minerals, as observed in other grasslands (Biondini et al 1998). Herbivores can facilitate nutrient cycling by trampling and fragmenting plant tissue, as well as by converting plant materials into dung and urine in which nutrients are more readily available to soil microbes and plants (McNaughton 1985; McNaughton et al 1988).

The negative effect of slope on $\mathrm{P}$ concentration, as well as that of aspect on $\mathrm{pH}$, could be due to nutrient loss through surface runoff. Northern aspects usually have higher levels of precipitation, thus facilitating loss of nutrients through surface runoff, a parameter also greater on steep slope sites (Biondini et al 1998; Chase et al 2000).

Finally, the variability in the response of some plant species cover to grazing intensity was related to aspect and slope, possibly due to their effect on soil $\mathrm{pH}$ and $\mathrm{P}$ concentrations. $F$. rubra cover was only affected by grazing at lower $\mathrm{pH}$ and $\mathrm{P}$ soil concentrations, ie, north steep slopes, whereas the reaction of A. capillaris cover to grazing intensity varied with $\mathrm{P}$ soil concentrations. Thus, at the same $P$ soil concentrations, grazing intensity reduced this species cover, whereas when $P$ soil conditions differed, the grazing intensity effect was inverted and the cover was lower under low grazing intensity.

\section{Conclusions}

Reduction of grazing intensity on calcareous grasslands with changing land use has led to changes in plant community structure, with shifts in plant species frequency and cover. Soil conditions, however, were also affected and, in some cases, favored the effect of grazing intensity on plant species cover as found for $F$. rubra or A. capillaris. Reduction in grazing intensity together with the effect of slope and northern aspect has resulted in changes in plant community structure, leading to increases in forages with lower nutrional value. On the other hand, A. capillaris, A. curtisii, $P$. erecta, and T. repens were sensitive to soil properties and aspect. Environmental factors such as aspect and slope affected plant community structure, most likely due to their effect on precipitation, surface runoff, and grazers' behavior. To quantify the impact of variable levels of grazing on plant community structure, it is necessary to recognize the variability in grazing that results from the interaction of environmental factors, resource supply, and animal behavior.

\section{Acknowledgment}

We sincerely thank anonymous reviewers for invaluable comments.

\section{Literature Cited}

Abacus ConCEPTS. 1996. StatView 4.5. Abacus Concepts. Berkeley, CA: University of California Press.

Albizu, I., S. Mendarte, G. Besga, M. Rodriguez, I. Amezaga, and M. Onaindia. 1999. Estructura de los pastizales de montaña y su relación con el pastoreo. In: SEP [ed.]. Actas de la XXXIX Reunión Científica de la Sociedad Española para el Estudio de los Pastos. Almeria, Spain. p 51-56.

aseginolaza, C., D. Gómez, X. Lizaur, G. Montserrat, M. R. Salaverria, and P. M. Uribe-EchebarRia. 1996. Vegetación de la Comunidad Autónoma del País Vasco. Servicio de Publicaciones del Gobierno Vasco. Vitoria-Gasteiz.

Bal, Y., Z. Abouguendia, and R. E. Redmann. 2001. Relationship between plant species diversity and grassland condition. Journal of Range Management 54:177-183.

Barandiaran, J. M., and A. Manterola. 2000. Ganadería y pastoreo en Vasconia. Bilbao: Etniker Euskal Herria. Bilbao. Herria. 1020 p.

Berg, W. A., J. A. Bradford, and P. L. Sims. 1997. Long-term soil nitrogen and vegetation change on sandhill rangeland. Journal of Range Management 50:482-486.

BIGNAL, E. M. 1998. Using an ecological understanding of farmland to reconcile nature conservation requirements, EU agricultural policy and world trade agreements. Journal of Applied Ecology 35:949-954.

Biondini, M. E., D. Patton, and P. E. Nyren. 1998. Grazing intensity and ecosystem processes in northern mixed-grass prairie, USA. Ecological Applications 8: 469-479.

BockDAM, J., AND J. M. GLEICHMAN. 2000. Effects of grazing by free-ranging cattle on vegetation dynamics in a continental north-west European heathland. Journal of Applied Ecology 37:415-431.

Bullock, J. M., J. Franklin, M. J. Stevenson, J. Silvertown, S. J. Coulson, S. GREgoRy, AND R. TOFTS. 2001. A plant trait analysis of responses to grazing in a long-term experiment. Journal of Applied Ecology 38:253-267.

Canals, R. M., and M. T. Sebastia. 2000. Analyzing mechanisms regulating diversity in rangelands through comparative studies: a case in the southern Pyrenees. Biodiversity Conservation 9:965-984.

Chase, J. M., M. A. Leibold, A. L. Downing, and J. B. Shurin. 2000. The effects of productivity, herbivory, and plant species turnover in grassland food webs. Ecology 8:2485-2497.

Daget, P., And J. Poissonet. 1972. Un procédé d'estimation de la valeur pastorale des pasturages. Fourrage 49:31-39.

DORMAaR, J. F., AND W. D. WILLMS. 1990. Effects of grazing and cultivation on some chemical properties of soils in the mixed prairie. Journal of Range Management 43:456-460.

Foster, B., AND K. Gross. 1998. Species richness in a successional grassland: effects of nitrogen enrichment and plant litter. Ecology 79:2593-2602.

Frank, A. B., D. L. Tanaka, L. Hofmann, and R. F. Follet. 1995. Soil carbon and nitrogen of northern Great Plains grassland as influenced by long-term grazing. Journal of Range Management 48:470-474.

Gillen, R. L., J. A. Eckroat, and F. T. McCollum. 2000. Vegetation response to stocking rate in southern mixed-grass prairie. Journal of Range Management 53:471-478.

HaRt, R. H., AND M. M. AshBy. 1998. Grazing intensities, vegetation, and heifer gains: 55 years on shortgrass. Journal of Range Management 51:392-398.

Hik, D. S., R. L. Jefferies, and A. R. E. Sinclair. 1992. Foraging by geese, isostatic uplift and asymmetry in the development of salt-marsh plant communities. Journal of Ecology 80:395-406.

Huntly, N. 1991. Herbivores and the dynamics of communities and ecosystems. Annual Review of Ecological Systems 22:477-503. 
KENT, M., AND P. COKER. 1992. Vegetation description and analysis. London, UK: Belhaven Press. 363 p.

KobaYASHI, T., Y. HORI, AND N. Nomoto. 1997. Effects of trampling and vegetation removal on species diversity and micro-environment under different shade conditions. Journal of Vegetation Science 8:873-880.

Krahulec F., H. Skalova, T. Herben, V. Hadincova, R. Wildova, and S. Pechackova. 2001. Vegetation changes following sheep grazing in abandoned mountain meadows. Applied Vegetation Science 4:97-102.

KULL, K., AND M. ZOBEL. 1991. High species richness in an Estonian wooded meadow. Journal of Vegetation Science 2:711-714.

Lavado, R. S., J. O. Sierra, and P. N. Hashimoto. 1996. Impact of grazing on soil nutrients in a Pampean grassland. Journal of Range Management 49:452457.

Manley, J. T., G. E. Schuman, J. D. Reeder, and R. H. Hart. 1995. Rangeland soil carbon and nitrogen responses to grazing. Journal of Soil Conservation 50:294-298.

Manly, B. F. J., L. L. McDonald, and D. L. Thomas. 1993. Resource selection by animals. Statistical design and analysis for field studies. London, UK: Chapman and Hall. $175 \mathrm{p}$.

mapa (Ministerio de Agricultura, Pesca y Alimentación). 1994. Métodos oficiales de análisis. Madrid, Spain: Secretaría General de Alimentación. 662 p.

Marisuan, S. 1996. El pastoreo en comunales. Estudio del comportamiento de las ovejas y la utilizacion de los recursos disponibles [Master of Science thesis]. Zaragoza, Spain: IAMZ. 165 p.

Marriot C. A., G. R. Bolton, G. T. Barthram, and K. Hook. 2002. Early change in species composition of upland sown grassland under extensive grazing management. Applied Vegetation Science 5:87-98.

Mathews, B. W., L. E. Sollenberger, V. D. Nair, and C. R. Staples. 1994. Impact of grazing management on soil nitrogen, phosphorus, potassium, and sulphur distribution. Journal of Environmental Quality 23:1006-1013.

McCracken, D. I., and E. M. Bignal. 1998. Applying the results of ecological studies to land-use policies and practices. Journal of Applied Ecology 35:961-967.

MclNTYRE, S., AND S. LAVOREL. 2001. Livestock grazing in subtropical pastures: steps in the analysis of attribute response and plant functional types. Journal of Ecology 89:209-226.

McNaughton, S. J. 1985. Ecology of a grazing ecosystem: the Serengeti. Ecological Monographs 55:259-294.
McNaughton, S. J., R. W. Ruess, and S. W. Seagle. 1988. Large mammals and process dynamics in African ecosystems. Bioscience 38:794-800.

Mikola J., G. W. Yeates, and D. A. Wardle. 2001. Effects of defoliation intensity on soil food-web properties in an experimental grassland community. Oikos 92:333-343.

Milchunas, D. G., and W. K. Lauenroth. 1993. Quantitative effects of grazing on vegetation and soils over a global range of environments. Ecological Monographs 63:327-366.

Milchunas, D. G., O. E. Sala, and W. K. Lauenroth. 1988. A generalized model of the effects of grazing by large herbivores on grassland community structure. American Naturalist 132:87-106.

Ostermann, O. P. 1998. The need for management of nature conservation sites designated under Natura 2000. Journal of Applied Ecology 35:968-973.

Reeder, J. D., and G. E. Schuman. 2002. Influence of livestock grazing on C sequestration in semi-arid mixed-grass and short-grass rangelands. Environmental Pollution 116:457-463.

Shannon, C. E., AND W. Wiener. 1963. The mathematical theory of communication. Urbana: University of Illinois Press. $116 \mathrm{p}$.

Stomlgren, T., L. D. Schell, and B. van den Heuvel. 1999. How grazing and soil quality affect native and exotic plant diversity in Rocky Mountain pastures. Ecological Applications 9:45-64.

Tansley, A. G., AND R. S. Adamson. 1925. Studies on the vegetation of the English chalk. III. The chalk grasslands of the Hampshire-Sussex border. Journal of Ecology 13:177-223.

van der Maarel, E., and A. Titlyanova. 1989. Above-ground and below-ground biomass related in steppes under different grazing conditions. Oikos 56:364370.

Watkinson, A. R., and S. J. Ormerod. 2001. Grassland, grazing and biodiversity: editors' introduction. Journal of Applied Ecology 38:233-237.

WEBB, N. R. 1998. The traditional management of European heathlands. Journal of Ecology 43:490-506.

WEST, N. E. 1993. Biodiversity of rangelands. Journal of Range Management 46:213.

XIONG, S., and C. NiLsson. 1999. The effects of plant litter on vegetation: a metaanalysis. Journal of Ecology 87:984-994. 